\title{
Zastosowanie symulacji numerycznych w badaniach ultradźwiękowych detali kompozytowych
}

\section{Application of numerical simulations of composite components ultrasonic testing}

\section{Streszczenie}

Symulacje numeryczne odgrywają coraz bardziej istotną rolę $w$ badaniach nieniszczących. Sa powszechnie wykorzystywane do opracowywania metod badawczych oraz potwierdzania ich skuteczności. Ich głównym celem jest wspomaganie analizy i interpretacji wyników badań. Artykuł pokazuje możliwości modelowania badań ultradźwiękowych na przykładzie badań zanurzeniowych detalu kompozytowego. W detalu wykonanym z kompozytu węglowo-epoksydowego zlokalizowane są wady celowo wytworzone przez zalaminowanie cienkich, płaskich, prostokątnych wstawek teflonowych o znanych wymiarach. Wykonano ultradźwiękowe badania zanurzeniowe detalu i porównano je $z$ wynikami symulacji przeprowadzonej dla utworzonego modelu numerycznego. Uzyskane wyniki dowiodły wysokiej wartości użytkowej symulacji numerycznej.

\section{Abstract}

Numerical simulations play an increasingly important role in nondestructive testing. They are widely used for the development of testing methods to confirm their effectiveness. Their main purpose is to support the analysis and interpretation of the research results. The paper shows the possibilities of ultrasonic testing modeling on immersion testing of composite test piece example. In the component made of carbon-epoxy composite, intentionally created defects are located. The defects were made by lamination of thin, flat, rectangular teflon inserts of known dimensions. The ultrasonic immersion tests of the component are compared with the results of simulations carried out for the created numerical model. The results showed the high value of the numerical simulation.

\section{Wstęp}

Kompozyty polimerowe wzmacniane włóknami tworzą współcześnie ważną grupę tworzyw konstrukcyjnych stosowanych w różnych rodzajach przemysłu, co zawdzięczają bardzo korzystnemu stosunkowi wytrzymałości mechanicznej do gęstości [1].

Zasadniczą metodą badań nieniszczących stosowanych do struktur kompozytowych jest obecnie metoda ultradźwiękowa. Bardzo duże możliwości oferuje tu technika Phased Array, która przy jednoczesnym zastosowaniu zautomatyzowanych badań zanurzeniowych umożliwia przyspieszenie inspekcji oraz zwiększenie rozdzielczości i precyzji lokalizacji ewentualnych nieciągłości w detalach kompozytowych [2, 3].

Dr inż. Łukasz Sarniak, dr inż. Maciej Szwed, mgr inż. Radosław Karczewski - Politechnika Warszawska.

W badaniach nieniszczących, a w szczególności w badaniach ultradźwiękowych, coraz bardziej istotną rolę odgrywają symulacje numeryczne, które są powszechnie wykorzystywane do opracowywania technik badawczych oraz potwierdzania ich skuteczności $[1,2]$. W pracy zaprezentowano możliwości modelowania badań ultradźwiękowych na przykładzie badań zanurzeniowych detalu kompozytowego.

\section{Metodyka badań}

Próbkę badawczą stanowi detal wykonany z kompozytu węglowo-epoksydowego $z$ wadami celowo wytworzonymi przez zalaminowanie cienkich, płaskich, prostokątnych wstawek teflonowych o znanych 


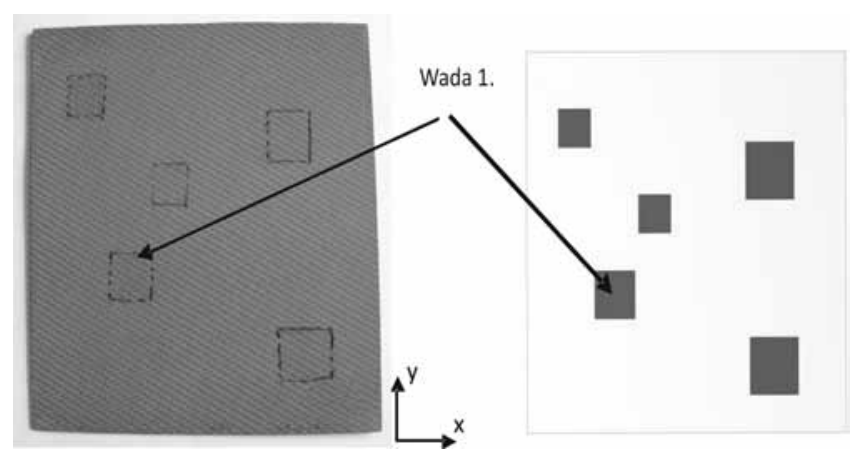

Rys. 1. Badanego detal $z$ oznaczonymi wadami oraz jego numeryczny model

Fig. 1. Picture of composite component with marked defects and its numerical model

wymiarach. Detal ma wymiary $250 \times 250 \times 2 \mathrm{~mm}$, a wstaw-

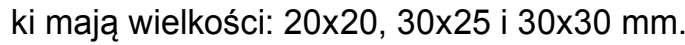

Za pomocą programu CIVA zbudowano model numeryczny badanego detalu, uwzględniając parametry, takie jak rodzaj materiału osnowy i zbrojenia, gęstość materiału, prędkość i współczynnik tłumienia fali ultradźwiękowej, sposób i gęstość ułożenia włókien oraz średnica włókna.

Następnie zbudowano modele wad, przy których charakteryzacji brano pod uwagę położenie wady w badanej próbce (współrzędne $x, y, z$ ), orientację względem próbki (nachylenie, obrót), geometrię (wada płaska, wada przestrzenna) oraz wielkość wady.

Badania ultradźwiękowe prowadzono za pomocą defektoskopu ultradźwiękowego Omniscan MX z systemem Phased Array firmy Olympus. Badania wykonano impulsową techniką echa $z$ użyciem zanurzeniowej głowicy wieloprzetwornikowej, 128-elementowej, o częstotliwości $10 \mathrm{MHz}$ - skan liniowy bez ogniskowania. Model głowicy ultradźwiękowej uwzględniał wszystkie istotne parametry, tj. częstotliwość pomiarową, ilość elementów piezoelektrycznych, odległości między elementami i ich wymiary oraz wymiary apertury aktywnej i całkowitej.

\section{Wyniki badań}

Dla założonych parametrów przeprowadzono symulację numeryczną, a jej wyniki zestawiono $z$ wynikami badań laboratoryjnych na rysunkach 2-8.

Wyniki otrzymane za pomocą symulacji numerycznej w dużym stopniu odzwierciedlają rezultaty badań laboratoryjnych. $W$ przypadku wszystkich ilustracji (A, B, C i D-Scan) występuje istotna zbieżność zarówno jeśli chodzi o lokalizację poszczególnych wskazań, jak i położenia oraz amplitudy uzyskanych sygnałów. Przykładowo, dla oznaczonej wady 1 :

$$
x=40 \mathrm{~mm}, \Delta x=30 \mathrm{~mm}, y=60 \mathrm{~mm}, \Delta y=25 \mathrm{~mm} \text {, }
$$

$z=0,8 \mathrm{~mm}$.

W przypadku modelu zarys wady w kierunku poziomym widoczny na wykresie B-Scan i C-Scan ma ostro

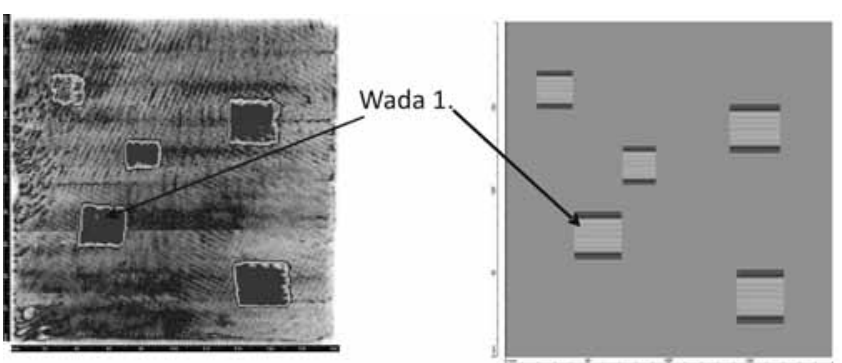

Rys. 2. C-Scan otrzymany w wyniku badań ultradźwiękowych oraz jego model numeryczny

Fig. 2. C-Scan acquired using ultrasonic testing and its numerical model
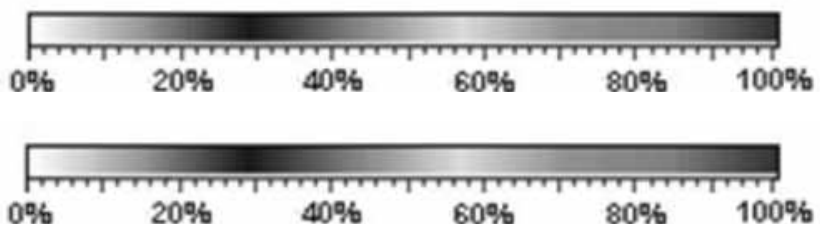

Rys. 3. Skale barw obrazujące amplitudę echa wady: a) Omniscan MX, b) CIVA

Fig. 3. Gain palettes: a) Omniscan MX, b) CIVA
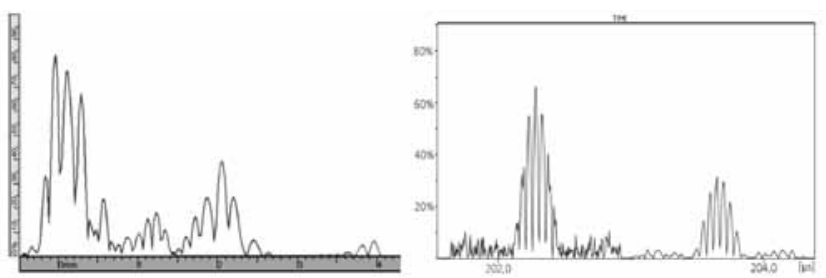

Rys. 4. A-Scan otrzymany w wyniku badań ultradźwiękowych w miejscu bez wad (po lewej) oraz jego model numeryczny (po prawej) Fig. 4. A-Scan acquired using ultrasonic testing in non-defected area and its numerical model
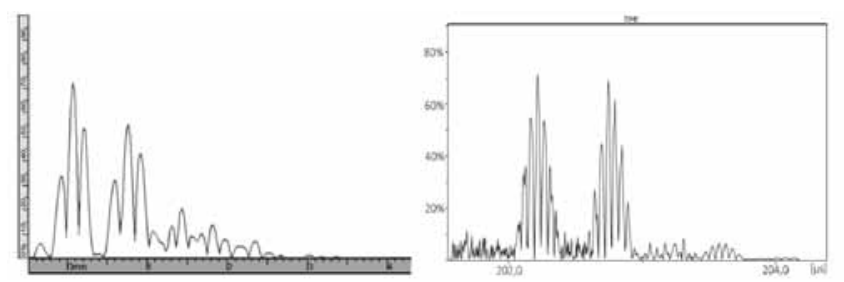

Rys. 5. A-Scan otrzymany w wyniku badań ultradźwiękowych w miejscu wady 1 (po lewej) oraz jego model numeryczny (po prawej) Fig. 5. A-Scan acquired using ultrasonic testing in defected area and its numerical model

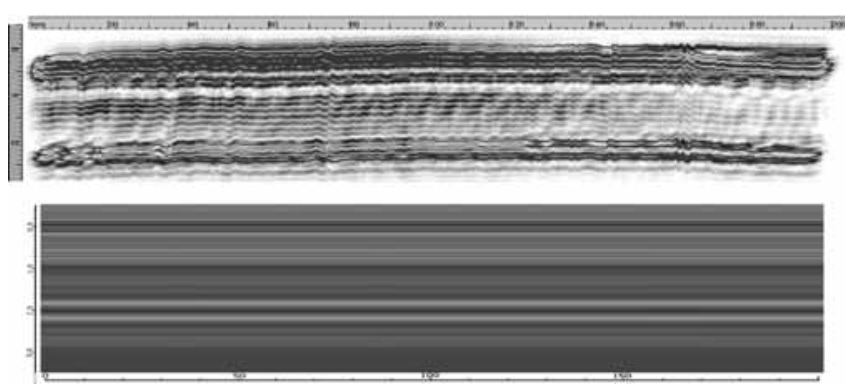

Rys. 6. B-Scan otrzymany w wyniku badań ultradźwiękowych w miejscu bez wad oraz jego model numeryczny (wartości podane w milimetrach)

Fig. 6. B-Scan acquired using ultrasonic testing in non-defected area and its numerical model 

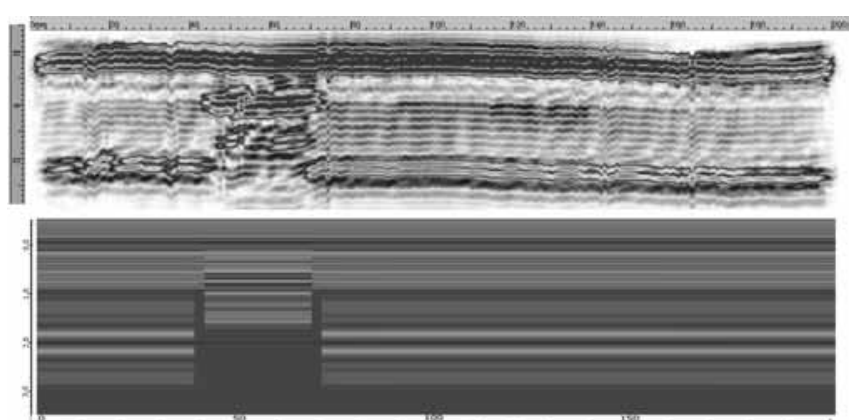

Rys. 7. B-Scan otrzymany w wyniku badań ultradźwiękowych w miejscu wady 1. oraz jego model numeryczny (wartości podane w milimetrach)

Fig. 7. B-Scan acquired using ultrasonic testing in defected area and its numerical model

zakończone brzegi, co jest związane ze zmniejszoną rozdzielczością modelowania $w$ osi $x$. Ograniczoną rozdzielczość wymuszał w tym przypadku czas niezbędny do wykonania obliczeń podczas symulacji. Wyniki symulacji numerycznej i wyniki otrzymane w wyniku badań laboratoryjnych różnią się także układem osi oraz paletą barw obrazującą amplitudę echa wady (rys. 3).

\section{Podsumowanie}

Otrzymane wyniki badań dowodzą jednoznacznie wysokiej wartości użytkowej przeprowadzonej symulacji numerycznej badań ultradźwiękowych kompozytów. Modelowanie może stanowić doskonałe narzędzie umożliwiające dobór aparatury badawczej, jej ustawień i parametrów ultradźwiękowych
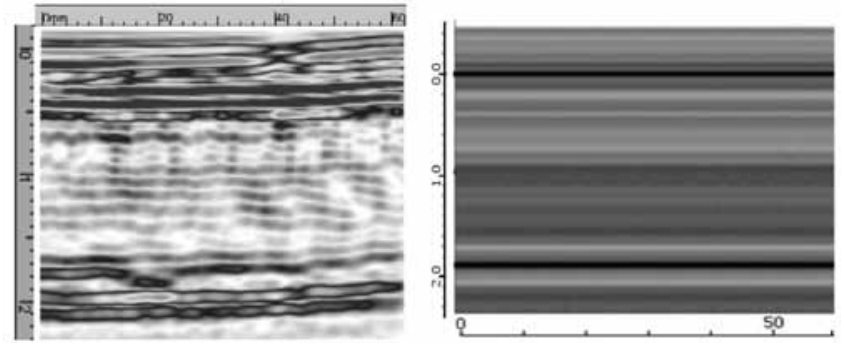

Rys. 8. D-Scan otrzymany w wyniku badań ultradźwiękowych w miejscu bez wad oraz jego model numeryczny (wartości podane w milimetrach) Fig. 8. D-Scan acquired using ultrasonic testing in non-defected area and its numerical model
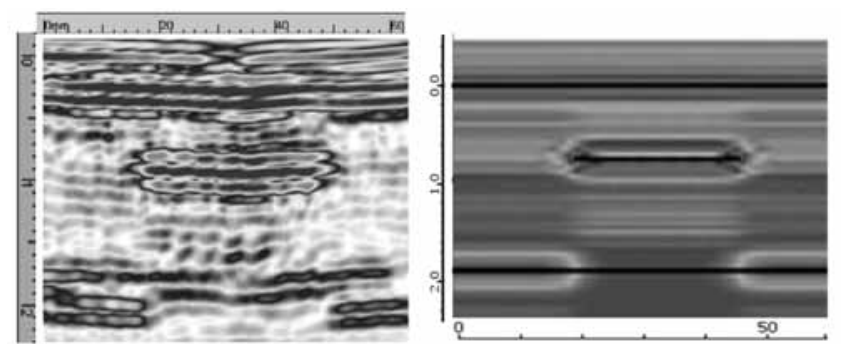

Rys. 9. D-Scan otrzymany w wyniku badań ultradźwiękowych w miejscu wady 1 . oraz jego numeryczny model (wartości podane w milimetrach)

Fig. 9. D-Scan acquired using ultrasonic testing in defected area and its numerical model

\section{Literatura}

[1] Mayer P., Kaczmar J.W.: Właściwości i zastosowania włókien węglowych i szklanych, Tworzywa sztuczne i chemia, 2008, nr 6.

[2] Sarniak Ł., Wielgat M., Szwed M., Kurzydłowski K.J.: Ultradźwiękowe badania laminatów z zastosowaniem głowic wieloprzetwornikowych, 40KKBN, Warszawa 2011

[3] SarniakŁ.: Opracowanie metodyki wykrywania za pomocą badań ultradźwiękowych wad powstających na etapie wytwarzania elementów kompozytowych stosowanych w lotnictwie, Politechnika Warszawska, Wydział Inżynierii Materiałowej, Warszawa, 2012 oraz interpretację wyników badań. Odpowiednio wykonana symulacja może także posłużyć do oceny wykrywalności wad oraz określenia prawdopodobieństwa ich wykrycia (POD) w elementach kompozytowych.
[4] Gengembre N., Calmon P., Petillon O. and Chatillon S., Prediction of ultrasonic fields into composite multi-layered structures: homogenization approach for the direct field and statistical approach for the inner reflections, Review of Progress in QNDE, 22, 2003

[5] Calmon P., Mahaut S., Chatillon S., Raillon R., CIVA: An expertise platform for simulation and processing NDT data, Ultrasonics 44, 2006 